\title{
Can Coalho cheese lactic microbiota be used in dairy fermentation to reduce foodborne pathogens?
}

Pode a microbiota lática de queijos Coalho ser usada como fermento para eliminar patógenos de origem alimentar?

\author{
G. M. P. Dias ${ }^{1 *}$; A. B. da Silva2; N. M. C. Granja²; T. N. da Silva ${ }^{2}$; G. V. M. \\ Lima $^{2}$; M. T. H. Cavalcanti²; A. L. F. Porto ${ }^{2}$ \\ ${ }^{1}$ Laboratório de Imunopatologia Keizo Asami, Universidade Federal de Pernambuco, 50670-901, Recife- \\ Pernambuco, Brazil \\ ${ }^{2}$ Laboratório de Tecnologia de Bioativos, Universidade Federal Rural de Pernambuco, 52171-900, Recife- \\ Pernambuco, Brazil
}

\author{
*diasgmp@gmail.com
}

(Recebido em 27 de novembro de 2018; aceito em 25 de fevereiro de 2019)

\begin{abstract}
In order to study the biodiversity of lactic acid bacteria (LAB) and evaluate their potential for use in dairy fermentation to inhibit foodborne pathogens, we collected two types of Coalho cheese made with raw milk from an artisanal production located in Venturosa, Agreste Region in the state of Pernambuco. From 480 isolates, 210 (Gram-positive; catalase-negative; able to clot skim milk) were identified as LAB and 78 were identified at genus level. The genera found were Enterococcus (37.1\%), Streptococcus (25.6\%), Lactococcus (19.2\%) and Leuconostoc (15.3\%). The technology potential showed that most of the LAB exhibited proteolytic activity (82.9\%), diacetyl production (65.7\%), grown in 3, 4 and $6.5 \% \mathrm{NaCl}$ (more than $50 \%$ ), and rapidly acidified milk (52.6\%) due to the production of lactic acid. The antagonistic potential showed that most LAB inhibited the growth of Staphylococcus aureus ATCC 6538 (82.89\%) and Escherichia coli ATCC 25922 (88.15\%), and $72.36 \%$ of the LAB presented antimicrobial activity against the two indicators. Among the Enterococcus strains, most (more than 70\%) were gama-hemolitic and none produced gelatinase. This study allowed for the selection of strains with promising potential for use in dairy fermentation that could reduce the contamination of milk and cheese by foodborne pathogens.

Palavras-chave: cheese, lactic acid bacteria, antagonistic and technology potential.
\end{abstract}

Para estudar a biodiversidade de Bactérias Ácido Láticas (BAL) e avaliar seu potencial para a utilização como fermentos lácticos capazes de inibir patógenos alimentares, dois queijos de Coalho produzidos com leite cru foram coletados de uma unidade de produção artesanal localizada na cidade de Venturosa, Região Agreste do Estado de Pernambuco. De 480 isolados, 210 (Gram-positivos; catalase-negativo; capaz de coagular o leite desnatado) foram identificados como BAL e deste, 78 foram identificados ao nível do gênero. Os gêneros encontrados foram Enterococcus (37,1\%), Streptococcus (25,6\%), Lactococcus $(19,2 \%)$ e Leuconostoc $(15,3 \%)$. O potencial tecnológico mostrou que a maioria dos BAL exibiu atividade proteolítica $(82,9 \%)$, produziu diacetil $(65,7 \%)$, cresceu em 3,4 e $6,5 \% \mathrm{NaCl}$ (mais de $50 \%$ ), acidificaram rapidamente o leite devido a produção de ácido láctico $(52,6 \%)$. O potencial antagônico mostrou que a maioria das BAL inibiu o crescimento de Staphylococcus aureus ATCC 6538 $(82,89 \%)$ e Escherichia coli ATCC 25922 (88,15\%) e 72,36\% delas, apresentaram atividade antimicrobiana contra os dois indicadores. Entre as cepas de Enterococcus, a maioria (mais de 70\%) foram gama-hemolíticas e não produtoras de gelatinases. Estes estudos permitiram a seleção de cepas com potencial promissor para uso como fermentos lácteos podendo reduzir a contaminação do leite por patógenos alimentares.

Keywords: queijo, bactérias ácido láticas, potencial tecnológico e antimicrobiano.

\section{INTRODUCTION}

Coalho cheese is one of the most traditional products produced and consumed in the Brazilian Northeast, especially in the states of Ceará, Pernambuco, Rio Grande do Norte, and Paraíba [1]. In the state of Pernambuco, this cheese is very important for the economy of small cities located in the Agreste Region and constitutes the main source of income and survival of 
the local population due to the simplicity of its production, organoleptic characteristics, and its high acceptance by consumers [2].

In the production of artisanal Coalho cheese in Pernambuco raw milk is traditionally used and allowed by law no. 15.192 of December $13^{\text {th }}, 2013$, even though Brazilian legislation for standardization and quality control recommends that cheese must be made from pasteurized milk [3]. This recommendation aims to produce high quality cheese, since raw milk is an excellent growth medium for foodborne pathogenic microorganisms and food spoilage microorganisms. Contaminated milk, besides spoiling easily, may pose a risk to consumer health [4]. However, pasteurization is one method commonly used to standardize microbial composition and improve the microbial safety of milk by reducing its microbial load and biodiversity [5].

Cheeses made from raw milk usually have a more intense aroma and flavor than those produced from pasteurized milk due to the biodiversity of Lactic Acid Bacteria (LAB) that naturally occurs as autochthonous microbiota in raw milk [6]. The LAB are generally recognized as safe (GRAS microorganisms) and play an important role in food fermentation and preservation either as natural microflora or as starter cultures added under controlled conditions [7].

In cheese-making the LAB may play different roles: some species participate in the fermentation process, whereas others are found in the maturation of cheese. In the first case, $\mathrm{LAB}$ rapidly ferments lactose producing high concentrations of lactic acid and are designated as starter LAB (SLAB), while LAB responsible for the ripening process are indicated as nonstarter LAB (NSLAB). In addition, the production of lactic acid by the starter flora during cheese manufacturing results in a $\mathrm{pH}$ decrease of the milk that in combination with stirring of the mass, promotes syneresis of the curd and expulsion of whey. Low $\mathrm{pH}$ values also inhibit the growth and survival of food-borne pathogens and food spoilage organisms [8].

Another important technological property of LAB is associated with its ability to produce extracellular proteases. These proteases play an important role in the degradation of casein and peptides, leading to the production of free amino acids and peptides [9]. These amino acids made from the proteolytic systems of starter bacteria may have a direct impact on flavor or serve as flavor precursors in these products, they are also essential in the growth of LAB, and fundamental parameters in the microbial ecology of the product [10].

The lactic acid microbiota present in dairy products are also responsible for the production of diacetyl, a volatile compound generated as an end product of the citrate metabolism, which gives cheese buttery flavors and highly develops odors [9]. Moreover, the LAB produce other aromatic compounds, such as acetic acid, ethanol, exopolysaccharides, several enzymes, and bacteriocins [11].

However, the biodiversity of Lactic Acid Bacteria (LAB) and all the food qualities attributed to them, could become extinct when milk used in the production of artisanal cheese is pasteurized. Thus, this study's objective was to select native LAB from Coalho cheese with the technological and antimicrobial potential to use in dairy fermentation. The LAB when added to pasteurized milk, besides promoting the return of the typical sensory quality of cheese made from raw milk, would reduce possible contamination of milk by foodborne pathogenic microorganisms. This would contribute in improving the quality of artisanal cheese, increasing its shelf-life, and consequently adding value to it.

\section{MATERIAL AND METHODS}

Two fresh samples of artisanal Coalho cheese, produced using raw bovine milk, were collected directly from production units located in the City of Venturosa, Agreste region of Pernambuco, Brazil. The samples were collected in the months of august and september of 2011 from according to the police agency of Pernambuco State Farming and analyzed in the Research Support Center of the Rural Federal University of Pernambuco.

Representative $25 \mathrm{~g}$ of Coalho cheese were homogenized with $225 \mathrm{~mL}$ of a sterile $2 \%(\mathrm{w} / \mathrm{v})$ sodium citrate solution (Vetec, Rio de Janeiro, Brazil). Serial dilutions $\left(10^{-1}\right.$ to $\left.10^{-9}\right)$ were 
prepared in $90 \mathrm{ml}$ of a sterile $0.1 \%$ (w/v) peptone water solution (Himedia, São Paulo, Brazil) [12]. One milliliter of these dilutions was spread in a plate containing APT agar (Himedia) for the isolation of the LAB [13]. The plates were inoculated in duplicate and incubated at 30 and $37^{\circ} \mathrm{C}$ for $48 \mathrm{~h}$ under aerobic conditions [14]. The total counts of bacteria were enumerated and the results were expressed as colony forming units (CFU) per gram of cheese. Samples were randomly taken from all the plates with a countable number of colonies (20-200 CFU per plate), of which 15-20 colonies were selected and collected for the purification step.

The isolates were purified by 3 cycles of subcultures on APT agar (Himedia) at 30 and $37^{\circ} \mathrm{C}$ for $48 \mathrm{~h}$ under aerobic conditions and stored in reconstituted skim milk at $12 \%$ (w/v) (Molico, Nestlé, Brazil) plus $15 \%$ (v/v) glycerol (Fmaia, São Paulo, Brazil), at $-18^{\circ} \mathrm{C}$.

Then, the strains were submitted to Gram staining, catalase activity test [12] and clotting ability reconstituted skim milk at $12 \%$ (w/v) [14]. The clotting ability was performed by adding an aliquot of $1 \%$ activated cultures onto reconstituted skim milk at $12 \%(\mathrm{w} / \mathrm{v})$ and incubated at 30 and $37^{\circ} \mathrm{C}$ for a period of 7 days or until coagulation. Coagulation of skim milk was indicative of lactic acid production.

The microorganisms catalase-negative, Gram-positive and capable of producing lactic acid were considered Lactic Acid Bacteria - LAB [13].

The LAB were classified of the according by Citti Sandine \& Eliker (1965) [15] as: a) strong acid producers (SAP): the ones with the ability to clot reconstituted skim milk at $12 \%(\mathrm{w} / \mathrm{v})$ in 18-48 h; b) weak acid producers (WAP), that coagulated after $48 \mathrm{~h}$; and c) non-producing (NP): without presenting clot ability of the environment within 7 days.

The LAB that presented cocci morphology was identified up to genus level according to Harrigan (1988) [12]. The following tests were applied for identification: a) growth at 10 and $45^{\circ} \mathrm{C}$ in $\mathrm{BHI}$ broth (Himedia) for 7 and 2 days, respectively; b) growth at $\mathrm{pH} 4.4$ and 9.6 in TSB broth (Acumidia, Baltimore-Maryland, EUA) for 30 and $37^{\circ} \mathrm{C}$ for $48 \mathrm{~h}$; c) growth in TSB broth in the presence of 4 and $6.5 \%$ of $\mathrm{NaCl}$ (Merk, Rio de Janeiro, Brazil) at 30 and $37^{\circ} \mathrm{C}$ for $48 \mathrm{~h}$ and d) production of carbon dioxide in MRS broth (Himedia) with $5 \%(\mathrm{v} / \mathrm{v})$ glucose in tubes containing Durham bells with $1 \mathrm{~cm}$ layer of sterile mineral oil. The reading of the results was performed within $18 \mathrm{~h}$ of incubation and at each $24 \mathrm{~h}$ for a period of 7 days.

The determination of extracellular proteolytic activity was performed according to the methodology described by Pailin et al. (2001) [16] modified by using the disk diffusion technique. For this activity, three disks of Whatmam filter paper of $\mathrm{n}^{\circ} 1$ of $6 \mathrm{~mm}$ were placed onto the surface of skim milk agar plates, in two discs were added volumes of $5 \mu \mathrm{L}$ of reactivated $\mathrm{LAB}$, except for negative control disk, which was added $5 \mu \mathrm{L}$ MRS broth (Himedia) plus $0.5 \%(\mathrm{w} / \mathrm{v})$ glucose (Merck) without microorganism. The plates were incubated at 30 and $37^{\circ} \mathrm{C}$ for $48 \mathrm{~h}$, followed by cooling in a refrigerator at $10^{\circ} \mathrm{C}$ for 3 days. The ability to produce extracellular proteases was indicated as a clear zone around filter paper disc with LAB. The measurement of halos was performed in millimeters with a pachymeter.

Diacetyl production was carried out as described by Ivanova et al. (2012) [17] and was determined as follows: LAB were skimmed milk powder at $10 \%(\mathrm{w} / \mathrm{v})$ medium, after a growth for $24 \mathrm{~h}$ at $30^{\circ} \mathrm{C}, 2 \mathrm{~mL}$ of each cell suspension was added with $0.2 \mathrm{~g}$ creatine (Merk) and $2 \mathrm{~mL}$ of $0.1 \mathrm{~N} \mathrm{NaOH}$ (Merk), followed by vortexing for 5 minutes. The production of diacetyl and acetyl methyl carbinol is indicated by the appearance of red color which was classified by color intensity as: Weak (W), Moderate (M), Strong (S) and Absent (A).

The test of survival at $\mathrm{NaCl}$ by carried as described by Harrigan (1998) [12]. For test sterile TSB broth (Acumidia, Baltimore-Maryland, EUA) with 3, 4 and 6,5\% $\mathrm{NaCl}$ (Merk) was inoculated using $3 \%$ of active tested strains. After $24 \mathrm{~h}$, the positive result was certificated by turbidity of TSB broth.

Acidification activity was measured by according method described by Ayad et al. (2004) [18], modified by altering the $\mathrm{pH}$ ( 6 and 24 hours). For Acidification activity, fifty milliliters of RSM was inoculated with $2 \%$ of culture at early stationary growth phase, the adjusted $\mathrm{pH}$ for 6,5 and then incubated at appropriate temperature. The $\mathrm{pH}$ was followed at 6 and 24 using a pH meter (Micro pH 2002, Crison, Barcelona, Spain). The cultures were considered as fast acidifying when reduce the $\mathrm{pH}$ to 5.3 in $6 \mathrm{~h}$ of incubation. 
The titrable acidity was determined by method described by Vázquez-Román et al. (2013) [19]. To measure Dornic acidity was added a drop of alcoholic solution of $1 \%$ phenolphthalein as an indicator of the color change point in $3 \mathrm{~mL}$ skimmed milk powder at $10 \%(\mathrm{w} / \mathrm{v})$ medium inoculated with $\mathrm{LAB}$ growth overnight. Then, titrated $0.01 \mathrm{~mL}$ of sodium hydroxide solution $(\mathrm{NaOH})$, until the sample changed color from white to light pink and the color change was maintained. Each $0.01 \mathrm{~mL}$ of $\mathrm{NaOH}$ necessary for the sample to change color corresponded to one Dornic degree $\left(1^{\circ} \mathrm{D}=0.1 \mathrm{~g}\right.$ of lactic acid $/ \mathrm{L}=0.01 \%$ of lactic acid $)$.

To evaluation of antagonistic activity, the foodborne pathogenic used were Staphylococcus aureus ATCC 6538 and Escherichia coli ATCC 25922 grown in BHI broth (Himedia) at $37^{\circ} \mathrm{C}$ for $24 \mathrm{~h}$. The LAB antagonistic activity against pathogens was performed according to the methodology described by Tagg et al. (1976) [20] modified by using the disk diffusion technique. For this activity, three disks of Whatmam filter paper $\left(\mathrm{n}^{\circ} 1,6 \mathrm{~mm}\right)$ were placed onto the surface of MRS (Himedia) agar plates. In two discs were added volumes of $5 \mu \mathrm{L}$ of reactivated cultures of $\mathrm{LAB}$, except for negative control disk, which was added $5 \mu \mathrm{L}$ MRS plus $5 \%(w / v)$ glucose, without microorganism. The plates were incubated at 30 and $37^{\circ} \mathrm{C}$ for $48 \mathrm{~h}$, followed by addition of $0.5 \mathrm{~mL}$ of chloroform in cover of plates, leaving it to act for 30 minutes at room temperature to remove microorganisms and remain only inhibitory substances. Then, semi-solid BHI agar containing $10^{6}$ of pathogenic microorganisms was added and incubated at $37^{\circ} \mathrm{C}$ for $24 \mathrm{~h}$ in aerobic conditions. The antagonistic activity was checked by the presence of inhibition zones around the discs. The measurement of the halos was performed in millimeters with a pachymeter.

The pathogenic potential of Enterococcus was evaluated by hemolysin activity described by Vergis et al. (2002) [21] and gelatinase production [22]. For the hemolytic activity, the Enterococcus strains were transferred BHI Agar plates containing 5\% defibrinated sheep blood and incubated at $37^{\circ} \mathrm{C}$ for $48 \mathrm{~h}$. The hemolytic reaction was classified as $\beta, \alpha$ and $\gamma$-hemolytic corresponded by total, partial and absent hydrolysis of red blood, respectively. Gelatinase production was detected by inoculation the Enterococcus in gelatin agar in incubated at $37^{\circ} \mathrm{C}$ for $48 \mathrm{~h}$. The appearance turbid zone around colonies reveled after addition of $500 \mathrm{~mL}$ of saturated solution of ammonium sulphate (Merk, Rio de Janeiro, Brazil) was considered to be a positive.

The data obtained of the proteolytic and antimicrobial activity and acidifying capacity were subjected to the analysis of variance, and, when significant, the averages were compared by Tukey's test, at $5 \%$ probability.

\section{RESULTS AND DISCUSSION}

The total viable counts of bacteria in the two cheese samples on APT agar plates under aerobic conditions varied in temperature and were in the range of $10^{7}-10^{9} \mathrm{CFU} / \mathrm{g}$. Overall, 480 isolates were collected from the two cheese samples. Most of the bacteria were obtained at a $30^{\circ} \mathrm{C}$ temperature of incubation, which corresponded to $81.25 \%$. At an incubation temperature of $37^{\circ} \mathrm{C}$, the percentage dropped to $64.17 \%$. These results were observed at the end of the purification cycle.

From 480 isolates, 218 were Gram-positive and catalase-negative. According to the cell morphology, among the Gram-positive and catalase negative bacterial isolates, 156 were coccilike, 34 were rod-like, and 20 were cocobacillus-like. Within all the cheeses a significantly larger number of cocci-like bacteria were isolated. Among the 218 bacterial isolates, 210 were able to clot skim milk and were confirmed as LAB (Table 1).

Other researchers also predominantly observed Gram-positive, catalase negative, and cocci morphology microbiota in artisanal and industrial cheeses, as well as in raw milk and fermented products $[23,24,25]$.

Among the $210 \mathrm{LAB}, 78$ with cocci morphology able to clot skim milk in $18 \mathrm{~h}$ were selected and submitted to be identified to genus level in a biochemical test (Table 2). 
Table 1. Classification of lactic acid bacteria (LAB) able t clot skim milk 12\% for a period of up 7 days.

\begin{tabular}{lccccc} 
& \multicolumn{3}{c}{ Morphology das LAB } & & \\
\cline { 2 - 4 } Production of acid & Cocci & Rods & Cocobacillus & isolated & n $^{(\%)}$ \\
\hline SAP (18h) & $\mathbf{7 8}$ & 19 & 11 & 108 & 51,43 \\
SAP (24h) & 18 & 1 & 4 & 23 & 10,95 \\
SAP (48h) & 32 & 12 & 3 & 47 & 22,38 \\
WAP & 28 & 2 & 2 & 32 & 15,24 \\
Total & 156 & 34 & 20 & 210 & 100,00 \\
\hline
\end{tabular}

SAP Strong Acid Producer; WAP Weak acid Producer; Results are expressed as number of samples; ${ }^{(\%)}$ Result express in percentage.

Table 2. Identification of genera of the lactic acid bacteria with cocci-like morphology isolated from the artisanal Coalho Cheese.

\begin{tabular}{lcccc}
\hline & \multicolumn{2}{c}{ Incubation temperature } & & \\
\cline { 2 - 3 } \multicolumn{1}{c}{ Genus } & $\mathbf{3 0}^{\circ} \mathbf{C}$ & $\mathbf{3 7}^{\circ} \mathbf{C}$ & Isolated & $\mathbf{n}^{(\%)}$ \\
\hline Enterococcus & 25 & 4 & 29 & 37,17 \\
Streptococcus & 13 & 7 & 20 & 25,64 \\
Lactococcus & 13 & 2 & 15 & 19,23 \\
Leuconostoc & 12 & - & 12 & 15,38 \\
NI & 02 & - & 2 & 2,56 \\
Total & 65 & 13 & 78 & 100,00 \\
\hline
\end{tabular}

Results are expressed as number of samples; ${ }^{(\%)}$ Result expressed in percentage; NI isolated Not Identified.

In this study the genus Enterococcus was the most abundant LAB (37.17\%) found. The high density of Enterococcus in dairy products like cheese and milk has been observed in many studies $[23,1,25]$. The high adaptability and resistance of Enterococcus is due to the production of volatile compounds (diacetyl, acetaldehyde, and acetoin) and enterocins, which may justify their prevalence in several types of dairy products [26].

Among the $78 \mathrm{LAB}$ evaluated, most exhibited proteolytic activity (82.9\%), diacetyl production (65.7\%), and growth in 3,4 and $6.5 \% \mathrm{NaCl}$ (more than $50 \%$ isolated). The mean values of proteolytic activity halos obtained by the samples of the genus Leuconostoc were statistically higher than those of the genus Streptococcus and Enterococcus, which differed significantly. According to the intensity of diacetyl production, 36 LAB were classified as weak, 10 moderate, and only 4 had a strong intensity. Among the genera, Streptococcus and Leuconostoc showed the largest number of isolates that produced diacetyl, 80 and $67 \%$, respectively. These results are presented in Table 3.

The production of high quality fermented dairy products is dependent on proteolytic systems of starter bacteria, since peptidase and amino acids have a direct impact on flavor or serve as flavor precursors in these products [10]. In addition, the production of diacetyl and acetoin impart buttery flavors and are responsible for the high development of odors [9]. The ability to tolerate salt in different concentrations is an important characteristic of LAB, which allows it to survive the salting stage that occurs during the process of producing cheese.

Our results are corroborated by Begovic et al. (2011) [24], who obtained proteolytic activity and $\mathrm{NaCl}$ tolerance for most LAB isolated from traditional Serbian cheeses. However, the results obtained for diacetyl production were not corroborated because only $4.1 \%$ of the LAB produced this volatile compound.

The characteristics of $\mathrm{pH}$ acidifications and titratable acidity of the LAB isolated from artisanal Coalho cheese are presented in Table 4. 
Table 3. Characteristics of the protease activity, diacetyl production and tolerance at $\mathrm{NaCl}$ of lactic acid bacteria isolated from artisanal Coalho cheese.

\begin{tabular}{|c|c|c|c|c|c|c|c|c|c|c|}
\hline \multirow[t]{2}{*}{ Genus } & \multirow[t]{2}{*}{$\mathbf{n}^{(0)}$} & \multirow[t]{2}{*}{$n^{(1)}$} & \multirow{2}{*}{$\begin{array}{l}\text { Proteolytic } \\
\text { Activity }^{(*)}\end{array}$} & \multicolumn{4}{|c|}{$\begin{array}{c}\text { Diacetyl } \\
\text { production }^{(2)}\end{array}$} & \multicolumn{3}{|c|}{$\begin{array}{c}\text { Tolerance } \\
\mathrm{NaCl}^{(3)}\end{array}$} \\
\hline & & & & $\mathbf{S}$ & $\mathbf{M}$ & $\mathbf{W}$ & $\mathbf{A}$ & $3 \%$ & $4 \%$ & $6,5 \%$ \\
\hline Enterococcus & 29 & 22 & $15,83( \pm 3,2)^{b}$ & 1 & 1 & 16 & 11 & 28 & 27 & 25 \\
\hline Streptococcus & 20 & 19 & $17,16( \pm 3,6)^{b}$ & 0 & 1 & 15 & 4 & 18 & 18 & 15 \\
\hline Lactococcus & 15 & 13 & $18,13( \pm 1,6)^{\mathrm{ab}}$ & 1 & 2 & 5 & 7 & 14 & 14 & 10 \\
\hline Leuconostoc & 12 & 9 & $20,50( \pm 3,6)^{\mathrm{a}}$ & 2 & 6 & 0 & 4 & 11 & 11 & 8 \\
\hline $\mathrm{CV}^{\%}$ & & & 5,8 & & & & & & & \\
\hline
\end{tabular}

Results are expressed as number of samples; ${ }^{(0)}$ total analyzed; ${ }^{(1)}$ Samples that exhibit proteolytic activity;

${ }^{(*)}$ Results are expressed as mean values $( \pm$ Standard Derivation) of proteolytic halo diameter: Means followed by equal letters do not differ by Tukey's test, at 5\% probability; ${ }^{(2)}$ Diacetyl production classified by intensity as $\mathrm{S}$ (Strong), $\mathrm{M}$ (moderate), $\mathrm{W}$ (Weak) and $\mathrm{A}$ (Absent); ${ }^{\left({ }^{3}\right)}$ Sample tolerant to $\mathrm{NaCl} ; \mathrm{CV}^{\%}$ Coefficient of Variation in percentage.

Table 4. Characteristics of acidify activity the of lactic acid bacteria isolated from artisanal Coalho cheese.

\begin{tabular}{|c|c|c|c|c|c|c|c|c|c|}
\hline \multirow{2}{*}{ Genus } & \multirow[b]{2}{*}{$\mathbf{n}^{(\mathbf{0})}$} & \multicolumn{4}{|c|}{$\mathbf{P h}$} & \multicolumn{4}{|c|}{ Lactic Acid } \\
\hline & & $\mathbf{n}^{(\mathbf{1})}$ & $\mathbf{6 h}^{(*)}$ & $\mathbf{n}^{(2)}$ & $24 h^{(*)}$ & $\mathbf{n}^{(3)}$ & $6 \mathbf{h}^{(\%)}$ & $\mathbf{n}^{(4)}$ & $24 h^{(\%)}$ \\
\hline Enter & 29 & 14 & $5.36^{\mathrm{aA}}$ & 23 & $4.33^{\mathrm{bA}}$ & 17 & 0.36 & 29 & 0.52 \\
\hline Streptoco & 20 & 08 & $5.36^{\mathrm{aA}}$ & 17 & $4.43^{\mathrm{bA}}$ & 15 & 0.32 & 19 & 0.50 \\
\hline Lactococcus & 15 & 10 & $5.23^{\mathrm{aA}}$ & 14 & $4.36^{\mathrm{bA}}$ & 06 & 0.40 & 15 & 0.54 \\
\hline Leuconostoc & 12 & 08 & $5.20^{\mathrm{aA}}$ & 10 & $4.43^{\mathrm{bA}}$ & 05 & 0.39 & 10 & 0.53 \\
\hline$C V^{(\%)}$ & & & & & & & & & \\
\hline
\end{tabular}

Results are expressed as the number of samples; ${ }^{(0)}$ total analyzed; ${ }^{(1)}$ Samples that reduced the $\mathrm{pH}$ to values $\leq 5.3 \mathrm{in} 6 \mathrm{~h} ;{ }^{(2)}$ Samples that reduced the $\mathrm{pH}$ to values $\leq 4.6 \mathrm{in} 24 \mathrm{~h} ;{ }^{(3)}$ Samples that presented values $\leq 40^{\circ} \mathrm{D}$ in $6 \mathrm{~h} ; \mathrm{n}^{(4)}$ samples that presented values $>40^{\circ} \mathrm{D}$ in $24 \mathrm{~h} ;{ }^{(*)}$ Means values followed by equal letters, lowercase in the lines and uppercase in the columns, do not differ by Tukey's test, at 5\% probability; ${ }^{(\%)}$ Percentage of lactic acid after 6 and $24 \mathrm{~h}$ incubations; $\mathrm{CV}^{(\%)}$ Coefficient of Variation in percentage.

The results of $\mathrm{pH}$ acidifications showed that $40(52.6 \%)$ of the LAB tested were classified as fast acidifying, since they were able reduce the milk $\mathrm{pH}$ to 5.3 in $6 \mathrm{~h}$ of incubation. The LAB that did not reduce the milk $\mathrm{pH}$ to 5.3 in $6 \mathrm{~h}$ of incubation were classified as secondary or adjunct cultures. There were no significant differences in mean $\mathrm{pH}$ values between the genera studied within 6 and $24 \mathrm{~h}$ of incubation. However, the acidification was higher after $24 \mathrm{~h}$ differing significantly. The results of titratable acidity revealed that 56.5\% LAB reduced the skim milk to values less than $40^{\circ} \mathrm{D}$ in $6 \mathrm{~h}$ of incubation. However within $24 \mathrm{~h}$, most $(96.0 \%)$ presented values above $40^{\circ} \mathrm{D}$. All $78 \mathrm{LAB}$ analyzed were lactic acid producers and the Lactococcus genus samples showed greater lactic acid producers after 6 and $24 \mathrm{~h}$ of incubation. Low $\mathrm{pH}$ values due to lactic acid production are important, since it reduces the risk in the growth of foodborne pathogens and food spoilage organisms [8].

Our results are corroborated by Cabral et al. (2016) [23], that analyzed the acidifying capacity of the LAB isolated from Coalho cheese made in the state of Pernambuco. After 24h of incubation, they obtained $\mathrm{pH}$ values ranging from 4.0 and 4.7. However, after $24 \mathrm{~h}$, the LAB cocci morphology, produced lactic acid between 0.55 and $0.75 \%$. Among the genera, Leuconostoc samples were classified as best lactic acid producers, which did not corroborate with our results. The results of the antagonistic potential of LAB against Staphylococcus aureus ATCC 6538 and Escherichia coli ATCC 25922, are presented in Table 5.

Most of the LAB from artisanal Coalho cheese inhibited the growth of S. aureus ATCC 6538 $(82.89 \%)$ and E. coli ATCC 25922 (88.15\%). This shows that LAB from the Agreste Region of Pernambuco are producers of antimicrobial substances that interfere with the development of 
foodborne pathogens, and thus assist in sanitary and microbiological cheese safety. In addition, $72.36 \%$ of LAB presented antimicrobial activity against the two indicators tested, and only $3.87 \%$ of LAB were not able to inhibit the growth of either pathogen.

Table 5. Evaluation of the antagonistic potential of lactic acid bacteria isolated from artisanal Coalho cheese against Staphylococcus aureus ATCC 6538 and Escherichia coli ATCC 25922.

\begin{tabular}{|c|c|c|c|c|c|c|c|c|c|}
\hline \multirow[b]{2}{*}{ Genus } & \multirow[b]{2}{*}{$\mathbf{n}^{(\mathbf{0})}$} & \multicolumn{3}{|c|}{ S. aureus } & \multicolumn{3}{|c|}{ E. coli } & \multicolumn{2}{|c|}{ Both } \\
\hline & & $\mathbf{n}^{(\mathbf{1})}$ & $\mathbf{n}^{(\%)}$ & $\begin{array}{c}\text { Antimicrobial } \\
\text { activity }^{(*)}\end{array}$ & $\mathbf{n}^{(\mathbf{1})}$ & $\mathbf{n}^{(\%)}$ & $\begin{array}{l}\text { Antimicrobial } \\
\text { activity }^{(*)}\end{array}$ & $\mathbf{n}^{(2)}$ & $\mathbf{n}^{(\%)}$ \\
\hline Enterococcus & 29 & 27 & 93.10 & $20.33^{\mathrm{bB}}$ & 26 & 89.65 & $22.83^{\mathrm{aA}}$ & 25 & 86.20 \\
\hline Streptococcus & 20 & 15 & 75.00 & $19.00^{\mathrm{bB}}$ & 16 & 80.00 & $21.00^{\mathrm{aA}}$ & 12 & 60.00 \\
\hline Lactococcus & 15 & 10 & 73.33 & $20.16^{\mathrm{aB}}$ & 14 & 93.33 & $20.66^{\mathrm{aA}}$ & 09 & 60.00 \\
\hline Leuconostoc & 12 & 10 & 83.33 & $24.83^{\mathrm{aA}}$ & 11 & 91.66 & $21.50^{\mathrm{bA}}$ & 09 & 75.00 \\
\hline Total & 76 & 62 & 81.57 & - & 67 & 88.15 & - & 55 & 72.36 \\
\hline $\mathbf{C V}^{\%}$ & & & & & & & & & \\
\hline
\end{tabular}

Results are expressed as the number of samples; ${ }^{(0)}$ Total analyzed; ${ }^{(1)}$ Samples that inhibited antimicrobial activity against a only pathogen; ${ }^{(2)}$ Samples that inhibited antimicrobial activity against both pathogen; ${ }^{(\%)}$ Percentage of LAB that showed antagonistic activity. ${ }^{(*)}$ Means values followed by equal letters, lowercase in the lines and uppercase in the columns, do not differ by Tukey's test, at $5 \%$ probability; $\mathrm{CV}^{\%}$ Coefficient of Variation in percentage.

Over $90 \%$ of the representatives from the genus Enterococcus and Lactococcus inhibited the growth of S. aureus ATCC 6538 (93.10\%) and E. coli ATCC 25922 (93.33\%), respectively. Additionally, the genus Enterococcus exhibited a great number samples (86.20\%) that are potentially antimicrobial for both indicators.

The largest averages of inhibition zones were obtained by the representatives from the genus Leuconostoc against $S$. aureus ATCC 6538, which differed significantly from the other genera studied. The average inhibition zone obtained by the representatives from the genera Enterococcus, Streptococcus, and Lactococcus didn't show significant difference when tested against E. Coli ATCC 25922.

The antagonistic action of LAB microflora naturally present in foods of animal origin has been described, particularly in relation to Gram-positive pathogens. Gram-negative cells are normally resistant to the action of the bacteriocin. However, in this study we found a high percentage of $\mathrm{LAB}$ with antagonistic potential against $E$. coli.

The results presented in this study corroborated with Cabral et al. (2016) [23], where most of the LAB isolated from Coalho cheese showed antimicrobial activity against at least one indicator. However, the results did not corroborate with Yang et al. (2012) [7], where only 28 $\mathrm{LAB}$, from a total of 138, exhibited antimicrobial activity.

The results from the pathogenic potential allowed the classification of the enterococcus strains as $\gamma$-hemolysin (72.4\%), $\alpha$-hemolysin (17.2\%), and $\beta$-hemolysin (3.4\%). Nevertheless, most LAB $(79.3 \%)$ are not gelatinase producers.

At the end of this preliminary technological characterization, a group of 12 strains, three from each genus, were selected as promising to use in dairy fermentation. These strains demonstrated considerable differences according to their industrially important traits. All 12 LAB selected showed the following characteristics: a) intense proteolytic activity due to the formation of peptidase and amino acids, which have a direct impact on flavor in the cheese; b) moderate production of diacetyl, because excess production of diacetyl can impart an undesirable flavor; c) resistance to different concentrations of salt that permit survival during the salting stage that occurs in cheese production; d) fast acidification that classifies the LAB as starter culture, as well as low $\mathrm{pH}$ values resulting in increased lactic acid producers that can inhibit the growth of pathogens; and e) antimicrobial activity against both indicator strains and among Enterococcus strains, only the non pathogenic were selected. 


\section{CONCLUSIONS}

The analysis of the technological potential of the LAB showed that they are promising to use in dairy fermentation. The LAB when added to milk could promote the return of the typical sensory quality of cheese made from raw milk, besides reducing possible contamination by inadequate manipulation. In addition, the LAB inhibits the growth of enterotoxigenic and pathogenic bacteria, such as Staphylococcus aureus and Escherichia coli, which suggests a possible reduction in the risk to consumer's health.

\section{ACKNOWLEDGEMENTS}

To Research Support Center of the Rural Federal University of Pernambuco for technician support.

\section{REFERENCES}

1. Freitas WC, Travassos ERA, Maciel JF. Avaliação microbiológica e físico-química de leite cru e queijo de coalho produzidos no Estado da Paraíba. Revista Brasileira Produção Agroindustrial. 2013;15(1):35-42, doi:10.15871/1517-8595

2. Silva RA, Bezerra VS, Pimentel BCM, Porto ALF, Cavalcanti MTH, Filho JLL. Proteomic and peptidomic profiling of Brazilian artisanal 'Coalho' cheese. Journal of the Science of Food and Agriculture. 2016;96(13):4337-4344, doi:10.1002/jsfa.7640

3. Brasil. Ministério da Agricultura. Portaria $\mathrm{n}^{\circ}$ 146, de 07 de março de 1996. Regulamento técnico de identidade e qualidade de queijos. Diário Oficial da República Federativa do Brasil, 11 mar. 1996. p. 3977-3978.

4. Ercan D, Korel F, Orsahin H. Microbiological quality of artisanal Sepet cheese. International Journal of Dairy Technology. 2014;67(3):384-393, doi:10.1111/1471-0307.12125

5. Bachmann HP, Frohlich-Wyder MT, Jakob E, Roth E, Wechsler D, Beuvier E, Buchin S. Raw milk cheeses. In: Fuquay JW, Fox PF, Sweeney PLH, editors. Encyclopedia of Dairy Sciences; 2011 Aug 652-660; San Diego: Academic Press, Elsevier Ltda.

6. Montel MC, Buchin S, Mallet A, Delbes-Paus C, Vuitton DA, Desmasures N, Berthier F. Traditional cheeses: Rich and diverse microbiota with associated benefits. International Journal of Food Microbiology. 2014;177:136-154, doi:10.1016/j.ijfoodmicro.2014.02.019

7. Yang E, Fan L, Jiang Y, Doucette C, Fillmore S. Antimicrobial activity of bacteriocin-producing lactic acid bacteria isolated from cheeses and yogurts. AMB Express. 2012;2(1):1-12, doi:10.1186/2191$0855-2-48$

8. Settanni L, Moschetti G. Non-starter lactic acid bacteria used to improve cheese quality and provide health benefits. Food Microbiology. 2010;27(6):691-697, doi:10.1016/j.fm.2010.05.023

9. Mukisa IM, Byaruhanga YB, Muyanja CMBK, Langsrud T, Narvhus JA. Production of organic flavor compounds by dominant lactic acid bacteria and yeasts from Obushera, a traditional sorghum malt fermented beverage. Food Science \& Nutrition. 2016;5(3):702-712, doi:10.1002/fsn3.450

10. Vasiee AR, Tabatabaei Yazdi F, Mortazavi A, Edalatian MR. Isolation, identification and characterization of probiotic Lactobacilli spp. from Tarkhineh. International Food Research Journal. 2014;21(6): 2487-2492.

11. Haiti S, Mandal S, Prajapati JB. Novel Starters for Value Added Fermented Dairy Products. Current Research in Nutrition and Food Science. 2013;1(1):83-91, doi:10.12944/CRNFSJ.1.1.09

12. Harrigan WF. Laboratory Methods in Food Microbiology. San Diego: Academic Press; 1998. 532 p.

13. Hall PA, Ledenbach L, Flowers RS. Acid-producing microorganisms. In: Downes FP, Ito K, editors. Compendium of methods for the microbiological examination of foods; 2001 Aug 201-207; Washington: American Public Health Association.

14. Carvalho JDG, Bruno LM, Nassu RT, Lima CP, Vasconcelos NM, Kuaye AY. Bactérias ácido láticas isoladas de queijo de Coalho artesanais comercializados em Fortaleza, CE. Revista do Instituto Cândido Tostes. 2005;60(345):221-224.

15. Citti JE, Sandine WE, Elliker PR. Comparison of slow and fast acid producing Streptococcus lactis. Journal of Dairy Science. 1965;48(1):14-18, doi:10.3168/jds.s0022-0302(65)88152-8

16. Pailin T, Kang DH, Schmidt K, Fung DYC. Detection of extracellular bound proteinase in EPSproducing lactic acid bacteria cultures on skim milk agar. Applied Microbiology. 2001;33(1):45-49, doi:10.1046/j.1472-765x.2001.00954.x. 
17. Ivanova G, Momchilova M, Rumyan N, Atanasova A, Georgieva N. Effect of Saccharomyces boulardii yeasts addition on the taste and aromatic properties of Kefir. Journal of the University of Chemical Technology and Metallurgy. 2012;47(1):59-62.

18. Ayad EH, Nashat S, El-Sadek N, Metwaly H, El-Soda M. Selection of wild lactic acid bacteria isolated from traditional Egypitian dairy products according to production and technological criteria. Food Microbiology. 2004;21(6):715-725, doi:10.1016/j.fm.2004.02.009

19. Vázquez-Román S, Garcia-Lara NR, Escuder-Vieco D, Chaves-Sánchez F, Cruz-Bertolo JL, PallasAlonso CR. Determination of Dornic Acidity as a Method to Select Donor Milk in a Milk Bank. Breastfeeding Medicine. 2013;8(1):99-104, doi:10.1089/bfm.2011.0091

20. Tagg JR, Dajami AS, Wannamaker LW. Bacteriocin of Gram positive bacteria. Bacteriological Reviews. 1976;40(3):722-756.

21. Vergis EN, Shankar N, Chow JW, Hayden MK, Snydman DR, Zervos MJ, Linden PK, Wagener MM, Muder RR. Association between the presence of Enterococcal virulence factors gelatinase, haemolysin and enterococcal surface protein and mortality among patients with bacteremia due to Enterococcus faecalis. Clinical Infectious Diseases. 2002;35(5):570-575, doi:10.1086./341977

22. Lopez MF, Simões AP, Tenenreiro R, Marques JJ, Crespo MT. Activity and expression of a virulence factor, gelatinase, in dairy enterococci. International Journal of Food Microbiology. 2006;112(3):208214, doi:10.1016/j.ijfoodmicro.2006.09.004

23. Cabral MLB, Lima MSF, Araújo GA, Costa EF, Porto ALF, Cavalcanti MTH. Queijos artesanais fonte de bactérias ácido láticas selvagens para formulação de fermentos tradicionais. Journal of bioenergy and food science. 2016;3(4):207-215, doi:10.18067/jbfs.v3i4.111

24. Begovic J, Brandsma JB, Jovcic B, Tolinacki M, Veljovic K, Meijer WC, Topisirovic L. Analysis of dominat lactic acid bacteria from artisanal raw milk cheeses produced on the Mountain Stara Planina, Serbia. Archives Biological Science Belgrade. 2011;63(1):11-20, doi:10.2298/abs1101011b

25. Mallesha R, Shylaja R, Selvakumar D, Jagannath JH. Isolation and identification of acid lactic bacteria from raw and fermented products and their antibacterial activity. Recent Research in Science and Technology. 2010;2(6):42-46.

26. Prichula J, Zvoboda DA, Pereiras RI, Santestevan NA, Medeiros AW, Motta AS, Alves D`Azevedo P, Giordani AR, Frazzon APG. Perfil de suscetibilidade aos antimicrobianos e diversidade das espécies de enterococci isolados de leite cru de búfalas do Sul do Brasil. Revista Brasileira de Ciência Veterinária. 2013;20(2):104-109, doi:10.4322/rbcv.2014.056 